\title{
The Best Forecasting Model For Cassava Price
}

\author{
Rahmi Yuristia'1), Dodi Apriyanto' ${ }^{2)}$, Ketut Sukiono3) \\ ${ }^{1}$ Dept. of Social Economics of Agriculture, Faculty of Agriculture, University of Bengkulu \\ 2Postgraduate Program in Agribusiness, Faculty of Agriculture, University of Bengkulu \\ ${ }^{3}$ Dept. of Social Economics of Agriculture, Faculty of Agriculture, University of Bengkulu \\ Corresponding Author: rahmiyuristia@unib.ac.id
}

ABSTRACT :This study aims to analyze and select the most accurate forecasting for predicting cassava prices in Indonesia. The data used is monthly data during the period of 2009 to 2017. This predicting uses the forecasting model, such as Moving Average, Exponential Smoothing, and Decomposition. Selecting the models found by comparing the smallest values of MAPE, MAD, and MSD. Therefore, it concluded that the Moving Average model is the most appropriate to Forecasting the price of cassava.

Keywords : Selection, Forecasting model, cassava, prices

Reference to this paper should be made as follows :

Yuristia, R, D. Apriyanto, and K. Sukiyono.2019 .The Best Forecasting Model For Cassava Price. Agritropica: Journal of Agricultural Science. 2 (2) : 86-92. Doi: https://doi.org/10.31186/Jagritropica.2.2.86-92

\section{INTRODUCTION}

Indonesia is a country that has various natural resources compared to other countries in the world. Abundant natural remedies can improve the economy to sustain food security in a region. Cassava is one food that can use as a substitute for rice or corn.

In Indonesia, Cassava has a significant economic value than other types of the tuber. In the arid regions in Indonesia, the function of cassava as a staple food because it is rich in carbohydrates. Humans can use almost all parts of the cassava plant, for example, as a vegetable and old leaves used as fodder, the stem is used as firewood. Products processed from cassava, among others: noodles, crackers, pluntiran, tiwul instant, bidaran, stick, tiwul gatot, and layer cake,
Demand for cassava throughout the entire region of Indonesia has growth of about $3.16 \%$ and productivity of 228.16 KU / Ha over the past five years (Pusat Data dan Sistem Informasi Pertanian, 2016). Cassava requests in a region so vary that it affects the difference in the price of cassava in each area. We can see cassava price development in Table 1.

Based on Table 1 shows that the volume of the price of cassava has increased from 2009 to 2017. The development of the cassava price at rural consumers not only increases every year but also every month and It rose to the highest rate in December 2017 about Rp. $276,160 / 100 \mathrm{Kg}$. Price stability in the future happens through a price forecasting approach. The purpose of this study was to find the best method of forecasting of the cassava price. 
Table 1. Development of Cassava Rural Consumer Price in Indonesia (Rp 100/kg)

\begin{tabular}{lrrrrrrrrr}
\hline $\begin{array}{l}\text { Month } \\
\text { year }\end{array}$ & $\mathbf{2 0 0 9}$ & $\mathbf{2 0 1 0}$ & $\mathbf{2 0 1 1}$ & $\mathbf{2 0 1 2}$ & $\mathbf{2 0 1 3}$ & $\mathbf{2 0 1 4}$ & $\mathbf{2 0 1 5}$ & $\mathbf{2 0 1 6}$ & $\mathbf{2 0 1 7}$ \\
\hline January & 170176 & 186450 & 197912 & 206663 & 217386 & 225011 & 245824 & 262116 & 268286 \\
February & 174212 & 188407 & 198762 & 207525 & 217192 & 226022 & 245401 & 261314 & 268667 \\
March & 174045 & 189835 & 199004 & 209392 & 217649 & 226617 & 249558 & 263296 & 268480 \\
April & 177395 & 189697 & 199247 & 210689 & 217987 & 226566 & 253062 & 263042 & 268006 \\
May & 177215 & 191122 & 198755 & 210980 & 217925 & 228039 & 253175 & 264263 & 269640 \\
June & 179078 & 191963 & 198915 & 212372 & 218398 & 231184 & 256186 & 264764 & 270046 \\
July & 180282 & 193123 & 201623 & 212949 & 221174 & 233396 & 257375 & 265390 & 269746 \\
August & 180484 & 194943 & 202979 & 215736 & 222306 & 233243 & 257446 & 265453 & 269161 \\
September & 183641 & 198262 & 203278 & 215619 & 221970 & 234256 & 259099 & 265561 & 271043 \\
October & 183029 & 197282 & 203448 & 216554 & 221834 & 238364 & 261349 & 263774 & 271200 \\
November & 187222 & 195668 & 204322 & 216345 & 221848 & 239617 & 262551 & 263429 & 273975 \\
December & 195036 & 196657 & 204990 & 216648 & 222207 & 243510 & 261978 & 264099 & 276160 \\
\hline
\end{tabular}

\section{MATERIALS AND METHODS}

This study using the data of rural consumer price of cassava development in Indonesia from 2009 to 2017. Total 98 observation model used in this study.

\section{Method of Moving Averages (moving average)}

Methods Moving Average (MA) is an indicator often used in technical analysis that shows the average value of the data during the period specified. Data averaged time-dependent data (time series). Moving averages are used widely in stock/forex technical analysis, prices to measure momentum, and determine areas of support and resistance that are possible. Simple Moving Average (SMA) used to create a smooth or smooth Stock/forex price curve and filter noise data so that it is easier to see the trend data (Irfan Abbas, 2016). The Formulas For Moving Averages Are :
$A_{t}=\left(D_{t}+D_{t-1}+D_{t-2}+\cdots .+D_{t-N+1}\right) / N$

Where:

$D t=$ data series

$\mathrm{N}=$ Total number of average periods

$A t=$ Prediction in period $\mathrm{t}+1$

\section{Decomposition Model}

In the decomposition method, there are additive and multiplicative decomposition models. Additive and multiplicative decomposition models can be used to predict a trend, seasonal, and cycle factors. The simple average decomposition method assumes the additive model, while the ratio decomposition method on the moving average (classical decomposition) and the Census II method assume a multiplicative model.The formulas are:

$\mathrm{Y}_{\mathrm{x}}=\mathrm{T}_{\mathrm{x}}+\mathrm{S}_{\mathrm{x}}+\mathrm{C}_{\mathrm{x}}+$

$I_{x}$ ( additive model) $Y_{x}=T_{X} X S_{x} X C_{x} X$ 
$\mathrm{I}_{\mathrm{x}}$ ( multiplicative model )

Where :

$\mathrm{Yx} \quad=$ periodic data period $\mathrm{x}$

$\mathrm{Tx} \quad=$ period $\mathrm{x}$ trend data

$\mathrm{Sx}=$ seasonal period (index) $\mathrm{x}$

period

$\mathrm{Cx} \quad=$ period $\mathrm{x}$ cyclical factor

$\mathrm{Ex} \quad=$ error factor $\mathrm{x}$

\section{Exponential Smoothing Model}

Exponential smoothing is a method that describes repetition procedures in continuous calculations using new data. The weighting system can be symbolized by a. A symbol can be freely determined to reduce forecast error. Smoothing constant values, a value of 0 can be chosen because it applies: $0<\mathrm{a}<1$ (Garspersz, 2004).

$$
S_{t}=a * X_{t}+(1-\alpha) * S_{t-1}
$$

$S t=$ forecasting for period $t$.

$\mathrm{Xt}+(1-\alpha)=$ Actual time series value

St-1 $=$ forecasting at time $\mathrm{t}-1$ (previous time)

$a=$ leveling constant between 0 and 1

\section{Size of forecasting results}

According to Wardah and Iskandar (2017), Measurement of forecasting is a measure of error about the slight difference between the results of predicting and actual demand. To calculate forecast errors are usually used Mean Absolute Percentage Error (MAPE), Mean Absolute Deviation (MAD), and Mean Square Deviation (MSD) (Sidik, 2010).

\section{RESULTS AND DISCUSSION}

The article on national price data throughout the territory of Indonesia is used to analyze data. This price data uses the last nine years period from January 2009 to December 2017. The cassava commodity price data is obtained from the secondary data of the Ministry of Agriculture Price Information System. The data collected is then analyzed with the following results:

Table 2.Descriptive data Analysis of Cassava Prices

\begin{tabular}{lrrrr} 
& Mean & $\begin{array}{l}\text { Standard } \\
\text { deviation }\end{array}$ & Maximum & Minimum \\
\hline Cassava prices & 225347,7 & 1917,63 & 276160 & 170176 \\
\hline
\end{tabular}

Based on the table. 2, it can be seen that the development of cassava prices has always increased over the past nine years. The highest price occurred in December 2018, while the lowest price occurred in January 2017. To forecast the cost of cassava in the future period, the forecasting model used in writing this article is by using the Moving Average Model, Exponential Smoothing,
Decomposition Models, Quadratic Trend Models, and ARIMA Models.

The aim is to compare and find out the best forecasting model for data on cassava prices for the future. The basis used to compare the best models is by looking at the value of MAPE (Mean Absolute Percentage Error), MAD (Mean Absolute Deviation), and MSD (Mean Square Deviation). If MAPE, MAD, and 
MSD have the smallest value, then the model is the best forecasting model.

\section{Moving Average (MA) Method}

Moving Average model estimation is presented to see the forecasting of cassava prices in the next period is order two movements in the -110 period. The model estimation results are shown in Figure 1. Visually the model estimation results are done five times from the three images. It can be seen that the line shows the forecasting value almost coincident or closest to the line representing the actual value is the forecasting value produced by MA (3). While for the forecasting value produced by MA (2) and MA (4), it is not too coincide with the line that represents the actual value. Thus MA (3) has a better value together based on the results of the comparison of MAPE, MAD and MSE values which can present in the following picture:
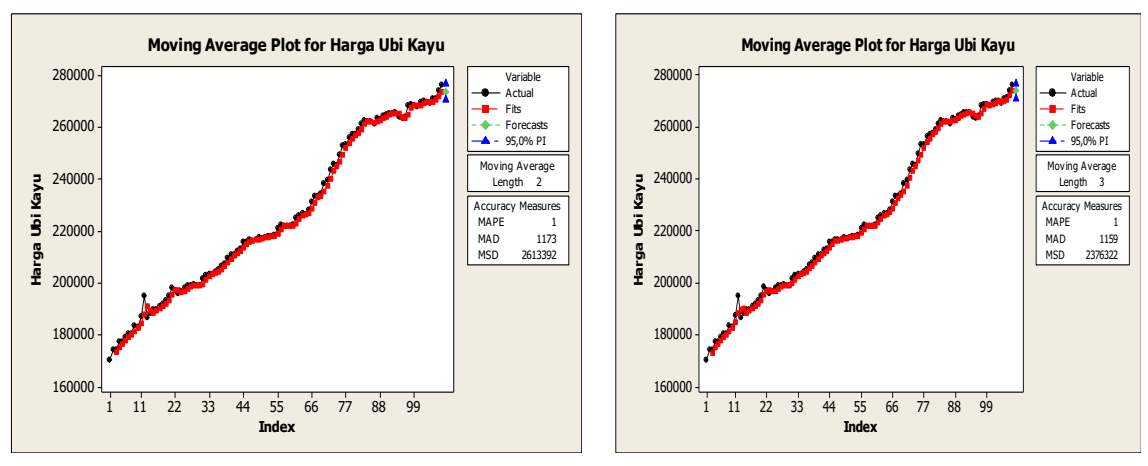

Picture 1

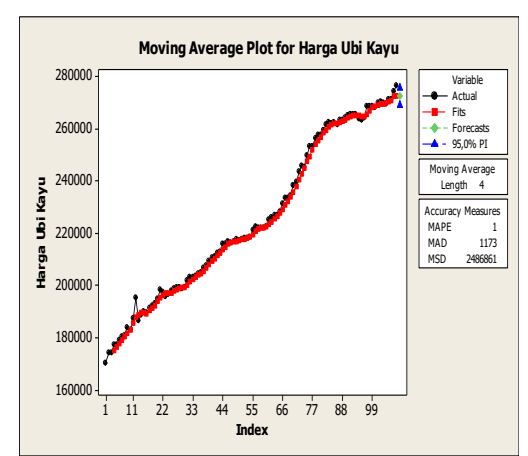

Estimation of the forecasting model results with Moving Average Models

Comparing all results between MA (2), MA (3), and MA (4) presented that MA results (3) have a better value because it found the smallest amount in MSE, MAD, and MPE. Thus the MA value (3) can be used as forecasting the price of Cassava at the level of rural producers in Indonesia with the Moving
Average model. The forecast value for the 110th period in February 2018 is Rp 273,778.00. The forecasting results inform the comparison of cassava prices in December 2017 is $\operatorname{Rp~276,160.00.~It~}$ means the price decrease about $\operatorname{Rp} 2$, 382.00 in February 2018.

Table 4. Comparison of forecasting models with moving average models

\begin{tabular}{lrrr}
\hline & MA2 & \multicolumn{1}{c}{ MA3 } & \multicolumn{1}{c}{ MA4 } \\
\hline Forecastingvalue $(\mathrm{Rp} / 100 \mathrm{~kg})$ & 273828 & 273778 & 272220 \\
\hline Forecasting Period & 110 & 110 & 110 \\
\hline \multicolumn{2}{l}{ Error criteria in the Moving Average Model Forecasting } & \\
\hline MAPE & 1 & 1159 & 1173 \\
MAD & 1173 & 2476322 & 2486861 \\
MSE & 2613392 & 23762
\end{tabular}




\section{Exponential Smoothing Method}

Exponential smoothing forecasting in this article uses a single exponential smoothing method. The exponential way is a weighting forecasting technique where data is weighting by an exponential function (Render and Heizer, 2005). Exponential smoothing has a more accurately level of accuracy compared to the moving average forecasting method even though it has similarities. The estimation results of the model using various levels of a $(0.1-0.9)$ presented in Table 5.

Table 5. Error values in the Single Exponential Smoothing Method

\begin{tabular}{cccc}
\hline A & MAPE & MAD & MSE \\
\hline 0,1 & 4 & 8697 & 89599771 \\
0,2 & 2 & 4555 & 27510683 \\
0,3 & 1 & 3140 & 14265189 \\
0,4 & 1 & 2465 & 9339467 \\
0,5 & 1 & 2077 & 7004366 \\
0,6 & 1 & 1824 & 5743450 \\
0,7 & 1 & 1643 & 5013520 \\
0,8 & 1 & 1517 & 4584614 \\
0,9 & 1 & 1438 & 4344500 \\
\hline
\end{tabular}

Based on Table 5, it is known that the best criteria are the modelwith the smallest error value that value of $a=0.9$, the MSE value 4344500, MAD value 1438 , and MAPE value 1. Based on this method, the price of cassava forecasts for the period of February 2018 is $\mathrm{Rp}$ 275,913 . From this forecasting method, it can be seen that there is a decrease in the price of cassava by Rp 247 in February 2018.

The decomposition method tries to identify ways that are separate from basic patterns that tend to characterize data series, especially economic and business data, to see stationary data. The following are the results of an analysis of cassava data using the Decomposition
Method, either the Additive Decomposition Method or the Multiplicative Decomposition Method.

\section{Decomposition Method}

Multiplicative and additive decomposition models are methods that are often used to generate predictions by regarding various factors such as trends (cycles), cycles, and seasonally. In figure (a) is a multiplicative decomposition model while in figure (b) additive decomposition. Multiplicative and additive decomposition models have different patterns; both approaches show the same slope trend. It has similar accuracy as a method of forecasting cassava prices. 

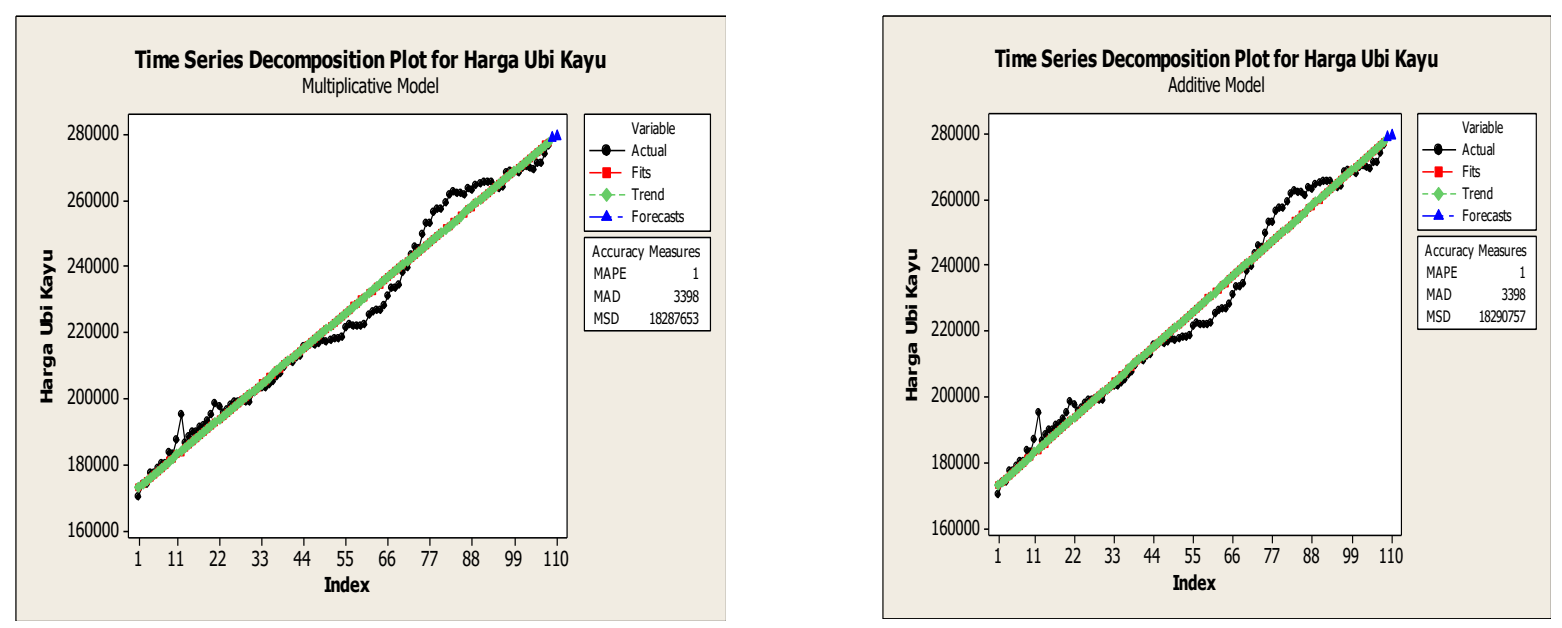

Picture 2. Comparison of Additive and Multiplicative Decomposition Methods

Table 6.Comparison of Additive and Multiplicative Decomposition Methods

\begin{tabular}{lccc}
$\begin{array}{c}\text { Decomposition } \\
\text { Methods }\end{array}$ & MAPE & MAD & MSE \\
\hline Multiplicative & 1 & 3398 & 18287653 \\
Additive & 1 & 3398 & 18290757 \\
\hline
\end{tabular}

From table 6 above, it can be seen that both methods give resultstend as same as the price of cassava forecast in February 2018 forMultiplicative and Additive Decomposition Methods, respectively, which is Rp 279379 and 279405. Decomposition models show that they have multiplicative and additive types. In world price, the most appropriateness method used in multiplicative price forecasting done because the value of MSE is smaller than other methods that meet the criteria of goodness.

\section{Accurate Model Selection}

Forecasting the price of cassava to predicting cassava prices has not yet occurred to forecast the cost of cassava in the future by using data on cassava prices from the past. Forecasting the price of cassava in this article uses the forecasting Moving Average method, the Exponential Smoothing model, and the Decomposition model. Of the three models, the most accurate model will be chosen to determine the best forecasting of cassava prices. Model selection is made by comparing the MAPE (Mean Absolute Percentage Error), MAD (Mean Absolute Deviation), and MSD (Mean Square Deviation) values of each model have done before. The results of the three models show in Table 7 as follows: 
Table 7. Forecasting Accuracy rates on cassava prices

\begin{tabular}{|c|c|c|c|c|}
\hline \multirow[b]{2}{*}{ Model Forecasting } & \multicolumn{3}{|c|}{ Accuracy Measure } & \multirow[b]{2}{*}{ Conclusion } \\
\hline & MAD & MSD & $\begin{array}{c}\text { MAPE } \\
(\%)\end{array}$ & \\
\hline \multicolumn{5}{|l|}{ World Price } \\
\hline Moving Average & 1 & 1159 & 2376322 & \multirow{5}{*}{$\begin{array}{l}\text { The Moving } \\
\text { Average is the most } \\
\text { appropriateness } \\
\text { model }\end{array}$} \\
\hline Exponential Smoothing & 1 & 1438 & 4344500 & \\
\hline Decomposition & & & & \\
\hline multiplicative & 1 & 3398 & 18287653 & \\
\hline additive & 1 & 3398 & 18290757 & \\
\hline
\end{tabular}

\section{CONCLUSION}

In this article, for forecasting the price of cassava using a forecasting model. Moving Average, Exponential Smoothing, and Decomposition have a different model and selecting the model by comparing the smallest MAPE, MAD, and MSD values among the three models. Moving Average model is the most appropriate method used for forecasting the price of cassava.

\section{REFERENCES}

Gaspersz, V. 2004. Production planning and inventory control. PT Gramedia Pustaka Umum, Jakarta.

Pusat Data dan Sistem Informasi Pertanian. 2016. Outlook Komoditas Pertanian Tanaman Pangan Ubi Kayu. Kementerian Pertanian.

Render, B. and J. Heizer. 2005. Operation Management, 7th edition Manajemen Operasi 7th edition, Book 1. Jakarta: Publisher Salemba Four.

Sidik, N. 2010. Forecasting Volume Produksi Tanaman Pangan, Tanaman Perkebunan Rakyat Kab. Magelang dengan Metode Exponential Smoothing Berbantu Minitab (Doctoral dissertation, Universitas Negeri Semarang).

Sukiyono, K., M. Nabiu, B. Sumantri, R. R.Novanda, N. N. Arianti, M. Z. Yuliarso and $\mathrm{H}$. Mustamam. 2018. Selecting an Accurate Cacao Price Forecasting Model. In Journal of Physics: Conference Series. 1114 (1), p. 012116). IOP Publishing.

Wardah, S., dan Iskandar. 2017. Analisis Peramalan penjualan Produk Keripik Pisang Kemasan Bungkus (Studi Kasus: Home Industry Arwana Food Tembilahan).J@ti Undip: Jurnal Teknik Industri, 11(3), 135-142. 